\title{
Holistic approach in Integrated Landscape Design. - Case Study for Montalvão Urban Park at Castelo Branco - Portugal
}

\author{
Rute Sousa Matos \\ University of Évora \\ Art and Art History Investigation Centre

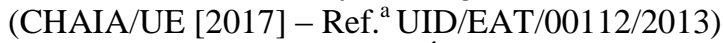 \\ University of Évora \\ Évora, Portugal \\ rsm@uevora.pt
}

\author{
Paula Simões \\ University of Évora \\ Art and Art History Investigation Centre \\ (CHAIA/UE [2017] - Ref. ${ }^{a}$ UID/EAT/00112/2013) \\ University of Évora \\ Évora, Portugal \\ pmss@uevora.pt
}

\begin{abstract}
This paper is the result of a theoretical research on the concept of landscape from a more comprehensive and general view, as an introduction to Mediterranean landscape, and more specifically, Portuguese landscape, which is included in the former. Some concepts are addressed by several national and international authors in order to get to the concept of landscape that we defend - holistic and multi-functional -, within which Mediterranean landscape, and within which Portuguese landscape is a paradigm. Since landscape is identity, the development of a nation, and a reflex of their culture, we deem it fundamental for landscape to continue being an identity and sustainable in spite of the general globalisation which we are witnessing, and to continue reflecting the will of the people. Hence, on this assumption, as well as bibliographic research, we have used the Portuguese common landscape as a concept for the construction of a space with contemporary landscape - Parque Urbano de Montalvão, in Castelo Branco -, which is the object of a tender. We hereby consider that the submitted bid recognises the value, character, and essence of this place, hence contributing with all that is necessary to safeguard the region's identity.
\end{abstract}

Keywords-Montalvão Urban Park; Castelo Branco; landscape architecture; multifunctionality, identity

\section{INTRODUCTION}

This study aims at pointing towards landscape as the identity of a culture, a nation, and a country. We also intend to propose the use of common landscape as methodology for the construction of contemporary landscape, which is already shown through the case study for Parque Urbano de Montalvão, in Castelo Branco - the object for the 2016 tender.

The used methodology was based on an extensive bibliographic research on the concept of landscape, Mediterranean landscape, and more specifically, Portuguese landscape, from which we headed on to the design of the landscape for the future urban park, which reflects the identity of Mediterranean landscape, more precisely Portuguese landscape.

From studying all the different landscape definitions $-1,2$, $3,4,5,6,7,8,9,10,11,12-$, we come to the conclusion that the concept of landscape is holistic, where living beings, animals and plants, and Man - who possesses a certain culture - act in a complex manner on a physical substrate leading to a certain image. Therefore, this image is much more than what you see; being the bearer of ecological and cultural definitions (the latter also include economic and social definitions). For the authors of ecological training, landscape is the 'sensory perception of the underlying ecosystem' (13). For the authors of aesthetic or literary training, landscape is the portion of space that you can reach with a quick glance.

In relation to the different approaches to the concept of landscape and its integration and articulation with different subjects, two great lines of thought have been developed over the past decades regarding the study and practice of landscape design: The ecological approach is based on a new view of the relations between Man and Nature and studies the responsible processes and activities for landscape morphology, structure, and dynamics. The perceptional and aesthetic approach, which considers landscape to be a formal manifestation and intends for the understanding of processes to contribute towards its visual and scenic quality and cultural and emotional definition.

The convergence of the several subjects and authors in the sense of integrating both approaches and perspectives - which have been observed over the past decades - into the concept of landscape reflects a return to lost multi-functionality, which is inherent to the concept of landscape, and accepting its understanding as a complex and dynamic system that results from cultural and natural processes that are constantly transforming.

A reflex of this return to multi-functionality is the entire issue that arose over the last decades of the 20th century around the spaces in-between the cities as a consequence of landscape sector distribution and zoning, which is the result of modern practices intended to be resolved since then (14). In this sense, many authors have given a lot of thought to this matter discussing, theorising, and practising new concepts and lines of thought. These may include the concept of 'Third Landscape' (15) and the concept of Urban Field (16), the line of thought on Landscape Urbanism (17), which was defended by many authors, and the concepts of Global Landscape and Region City (18). 
Therefore, we believe that the - global - landscape should be understood as an open system where urban tissues and cultural mosaics consistently interrelate - as a cultural product and a product of society.

Thus, an approach to landscape should include an inclusive and multi-functional holistic belief of landscape. This is the concept of landscape that we believe in and defend in this project, since we understand that landscape is a phenosystem and a cryptosystem at the same time considering the holistic notion of this concept and its operative and pro-active character. This landscape that is integrating and multifunctional, inclusive and holistic, phenosystemic and cryptosystemic, and the cultural identity of a nation has been found in the construction of Mediterranean landscape since its origin.

Many authors (19, 20, 21, 22, 23, 24, 25, 26, 27, 28, 29, 30, 32) among others have given a lot of thought to studying the Mediterranean with many works appearing over the past century. We believe that the author to have studied this cultural unit more clearly and profoundly was (21), who expressed it as follows: In both physical landscape and human landscape, the crossroad Mediterranean, the whimsical Mediterranean comes to our memories as a coherent image, as a system where everything comes together and collects itself in an original unit. How can one explain this clear unit, this profound being of the Mediterranean? We have to make an effort once or twice in order to understand it. It is not solely explained by nature, which has worked hard for this purpose; or not only by Man who has stubbornly connected it all; but rather the graces of nature, or its curses - one or the other are numerous - and multiple efforts by men, today as in the past. That is, an endless sum of repeated bad luck, accidents, and success.

Mediterranean landscape offers itself to our gaze as a history of the reflected efforts of men. In this sense, it is the manifestation of a will, since those who built it identify with their work and seek to use nature's resources without luxury. This is how a peasant, an engineer, and an architect, among others, are blended into their land or space used for their life or activity among this barbaric nature that is the object of their struggle while they are themselves aware of their capacity to subdue without destroying. We call this mediation harmony, which expresses the will to regain the conscience of a reflected struggle in the appearance of this individual or collective work.

The terraces, the vegetable garden, the forest, and characteristic Mediterranean landscapes illustrate perfectly this will of the people to build a life project using nature elements and a production that is concerned with the squandering of natural resources. To destroy nature in a merciless fight will mean that all those who drew up this landscape will annihilate themselves, since these people came from nature itself. Therefore, the will to mediate the creatures, the landscape, and matter, the reasonable exploitation of the earth, the plants, and the animals has a long history.

From knowledge, which was many times acquired at the expense of tragic events, came the understanding of how to build space with living matter in such a way that the Mediterranean landscape still permits us to contemplate it nowadays. Most plants were planted and domesticated around the Mediterranean, always seeking improvement. The most elaborate water techniques were also imagined around the Mediterranean.

Historic confrontations, social divisions, and natural accidents did not undo the extraordinary tenacity of Mediterranean people to imagine and build this landscape.

In terms of understanding the space and the interrelation between its natural and cultural aspects - although they were not exclusively focused on the concept of landscape and its character -, the works of $(19,20,22,29,30$, and 33) should be mentioned in Portugal. However, the work of reference for the past decades has been that by (32), which remains a fundamental contribution to the understanding and characterisation of the complexity of Portuguese landscape. It reflects a sensitive analysis of the relation between the natural and cultural factors that constitute a dynamic system resulting in landscape, in terms of common features as well as contrasts. The author refers to the relation between the natural and cultural factors of landscape as follows: North and South, Coast and Inland, High and Lowlands; these are the threads for the rich fabric in our regions and landscape. The rich array of Portuguese landscapes and the regional variety that results from them combined has a physical basis (...) Man explores these contrasts in relief, exposure, rock nature, climate, and local aptitudes, which grant a polymorphic physiognomy to the most part of agrarian landscape.

By experiencing such landscape - particularly that which has undergone successive transformations throughout time and has managed to preserve a certain authenticity -, it has become obvious that History is embedded into the landscape and that this landscape is a part of the natural conditions with long and specific human actions, which reflect the natural and cultural history of a territory, thus resulting in a unique ensemble for each case. This uniqueness in each landscape - albeit dynamic - is equivalent, according to (34), to genius loci - a place's spirit or character.

(32) refers to the role of landscape for the local and regional identity by stating that the landscape of today corresponds to a product of the past and constitutes a record of collective memory. (35), in As Regiões Portuguesas, also defends that landscape is a powerful element of cultural identification, which may be compared to language and religion. Let us then understand through the following case study how the construction of contemporary landscape can continue being an identity factor.

\section{CONCEPT}

Located in one of the main entrances to the city, the park being designed for Cruz de Montalvão takes the form of urban life whose image and ambience is anchored into the rural roots that make up the identity of the population of Castelo Branco. (Fig.1)

Its function as a space for resting and socialising is based on a philosophy of profound respect for the natural values (preserving ecological systems, processes, and flows) and cultural values (emphasising and maximising costumes and traditions) that constitute the soul of these people integrating 
them into the landscape and turning them into an indissoluble element, one of a kind (people and landscape) (36). Look at how one of the greatest artistic singularities that is the identity of this country - the embroidery of Castelo Branco determined and was determined by landscape: the cultivation of flax and the cultivation of mulberry trees have enabled to raise silkworms in large quantity.

Looking around us, in the surrounding environment, we can easily recognise the references that witness this bond between Man and landscape as well as the elements that constitute the city's memory granting it an identity. These references and memories were those considered fundamental for the project: the Castra Leuca and the Castle, Serra da Gardunha and Serra da Estrela, and the heritage surrounding the park (cultural heritage - rubble walls and military elements; and natural heritage - the different tree species that exist). Urban art is intended to take place in a contemporary act through this heritage, this memory. Sometimes, through its reinterpretation, other times through interventions highlighting them, transforming them, replicating them, building a bridge between the past and the future, between a memory and tactile experience, between the indigenous and innovation.

To the south of the Beira Baixa railway, right after the urban centre, the Barrocal bears dry oak specimens with enormous round-shaped granite rocks moulded by the climate, which although it is mild, is strongly characterised by the Mediterranean and continental influence. The urban space has been built in this granite landscape. Castelo Branco is a city of extremes: it has little humidity throughout the year and rainfall, and sometimes even snow transforms the city in the cold season; while in the summer there is residual rainfall and the high temperatures limit the levels of climate comfort felt in the city.

Sustainability, whose foundations - the environment, society, and economy - bring it closer to the concept of landscape - disclosing in itself the same principles -, determines among other purposes the need to include the population but also to reuse the landscape systems - existing legs, water, and vegetation - as a means to ensure, promote, and capitalise: the accessibility system (by reusing pre-existing legs); the reuse of matter in order to reduce energy consumption (water - collecting rainwater by means of drainage and reuse for irrigation); microclimate regulation (through the use of vegetation); and hence take active part in mitigating the consequences of climate changes.

Simultaneously to our desire to design a project that offers the most coherent and innovative solutions integrating the community that receives it, we have also designed it with the place of intervention's ecological, cultural, and social memory, thus promoting the population's ecological awareness. By characterising, interpreting, and systematising the place, structuring and fundamental lines have been mentally revealed, which determined this landscape according to its genius loci. (Fig. 2)

The creation of a multi-functional landscape space in an ecological form, which is social and economically executable, where the presence of nature welcomes the practice of city activities - cultural, sport, artistic, and spiritual -, determines that the narrative of the proposed simple and sober design should emphasise the topo-morphology that embodies the park by formalising lines, surfaces, and points that highlight ridges and thalwegs consolidating and ramifying this space with its surroundings combining them and turning them into a cohesive unit.

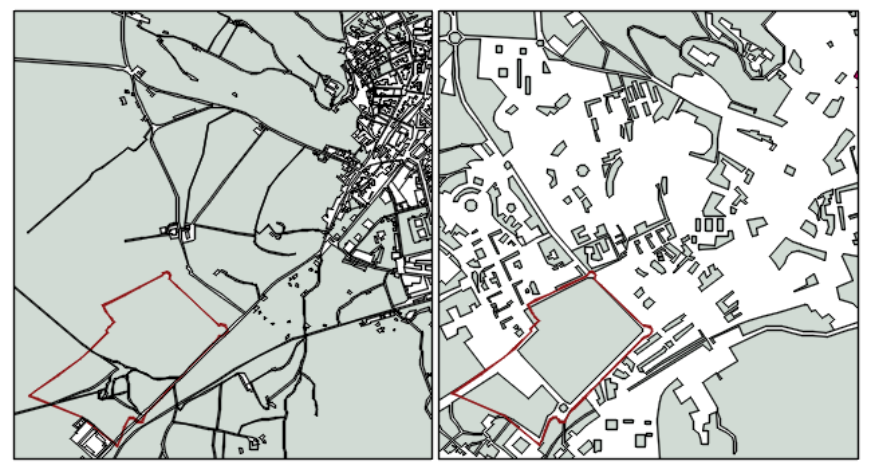

Figure 1. Urban fabric evolution until the inclusion of the park (1950 vs 2016)

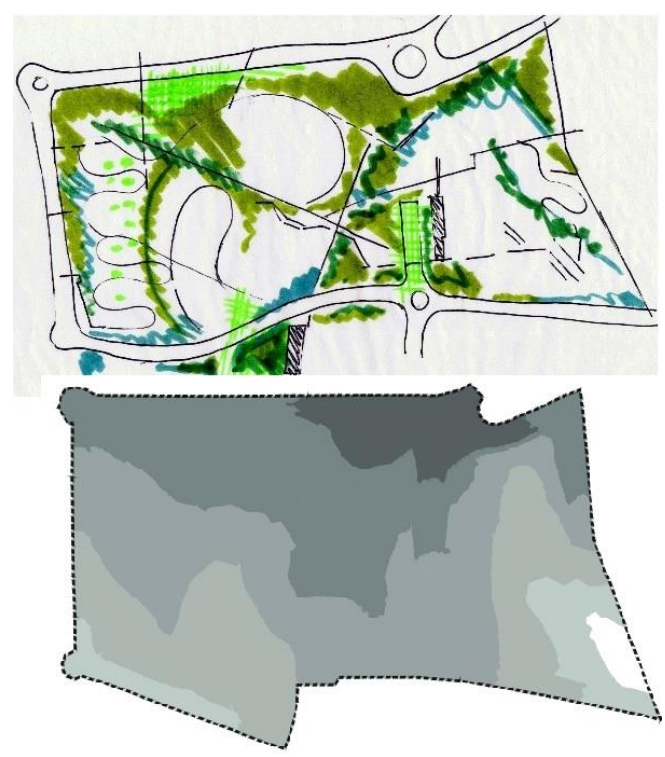

Figure 2. The structure of the park based on landscape

\section{NARRATIVE OF THE FORMS | PROJECT DESIGN}

Art, technique, and science design and emphasise a landscape that is honoured with and offers itself in urban space within a promiscuous relationship with the urban life that is felt therein. They embody a narrative that reads, writes, and ensures ecosystem continuity of the landscape, it encourages contact with nature, relaxation, production, and protection; that is, a multi-functionality that is inherent to the landscape and sustainability is designed, hence contributing in a very positive manner to the emotional and physical state of the population. Silence, tranquillity, freshness, light, shadow, ecological diversity, and freedom add to the city space.

Unit (a hyphen between the north and the south) 
The access through Avenida do Empresario is the shortest yet most efficient connection that will transform a structural difficulty into an enormously singular place. Conceptually, this access will contain the unit within it: in the flows, processes, and matter, as well as the memories and contemporary world, within a balance that bears an orthogonal outline underlying the city's own outline.

Resilient and subtle - in addition to the formal and physical connection provided by technology -, the design will transform a cleavage into a connection that formalises itself in a building/access and hyphenates the systems that build the landscape. This building/hyphen combines support equipment, sanitary facilities, cafeteria, and storage. It unfolds and groups together into a set of movable modules throughout the park allowing for activities that stimulate the park's agenda: concerts, fairs, circuses, temporary bullfights, exhibitions, various types of celebration, and the promotion and enlivening of urban art, which will also be possible in these modules, as well as the diagonal support walls.

These modular constructions will be light, clean, contemporary, subtle, discrete, and will meet a dynamic, interactive, and movable functional programme. In an analogy to the shape of a tree trunk, they are shaped like regular angles (triangular and hexagonal) and, similarly to the main building, they are coated with cork, thus they are one with the park's landscape, also due to their matter. (Fig. 3)

This building conceptually and symbolically unifies the visual point that lies over the two morphological subunits. This is the ridge where, in terms of topography, the two small basins containing the park touch and turn into the structuring element for the entire design. (Fig. 4)

The Hyphen - which is the structure connecting the two spaces that currently make up this park - appears as much more than an element that was built to solve a functional programme. It is, in all essence, the connecting link for the practical solution physically connecting the park's spaces and programme, as well as the element germinating the concept of a building that connects to a land, a building that springs from the ground and germinates, grows, and expands in an autonomous and solid form that agrees with the landscape around it. It is a central element of the park, an element of strength, although it is almost anonymous. Partially buried, discrete among the vegetation, with profound respect for the topo-morphology and species to be preserved, hence maintaining a dialogue with the latter. The social spaces particularly the cafeteria, patio, and terrace - relate directly to the open space and the systems that constitute it.

The building's subtlety is also granted by the great glazed area that appears on the surface through the external engineered cork layer.

The strong and remarkable option to use a cork layer on the main building as well as the proposed modules is due to: the relevance of the material in this context; the desire to integrate the building with the park's landscape; the practical way to solve the will to make the building 'disappear' and the response to the sustainability that was assumed as project principle. The cork layer grants the building solidity, looks, integration, and the necessary energy classification.

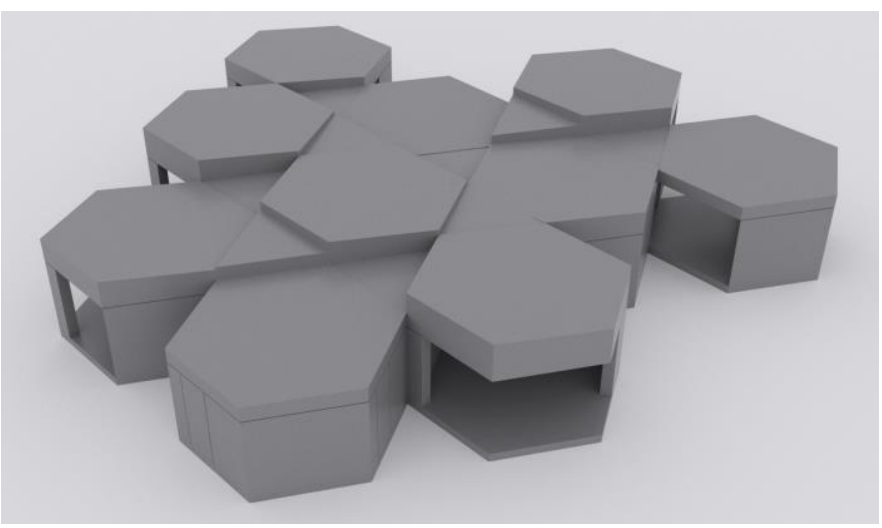

Figure 3. Modular constructions

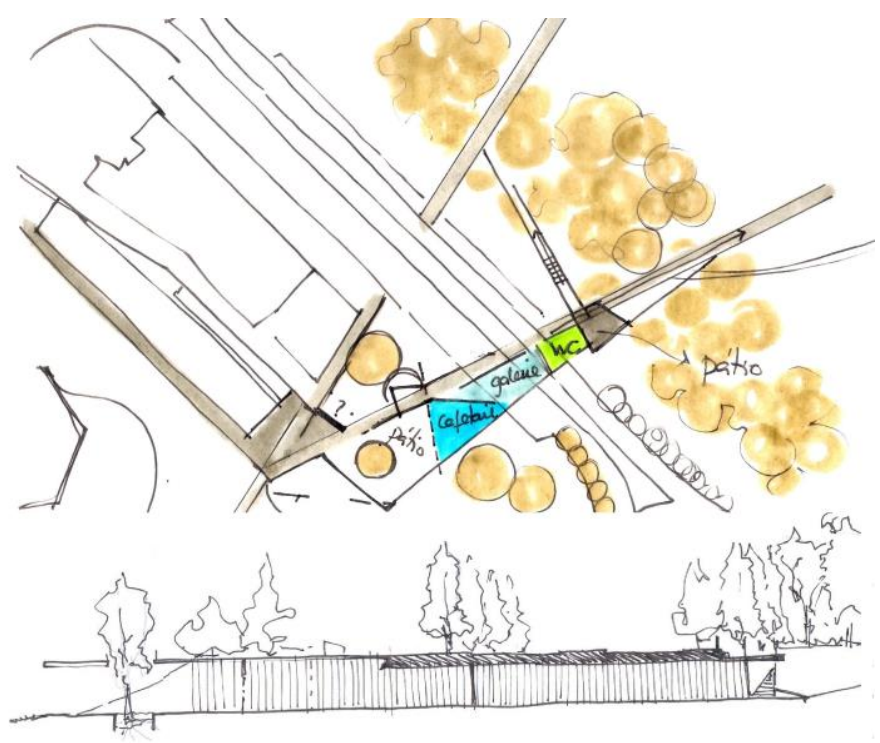

Figure 4. The building integration in land morphology

\section{ARTICULATION}

Because sociability is a pillar of sustainability, we intend to encourage proximity with the highly urbanised neighbourhoods around this open space. The extended Avenida Professor Doutor Egas Moniz - where the road continues to the west -, the extended parking areas, the free enlargement of pavements without compromising safety in terms of the road hierarchy that outlines them, the start and extension of the cycling path through the park towards the north of the city, through Quinta Dr. Beirão, promote this proximity and the park's integration in the city.

The proposed cycling path will cross the park diagonally rather than peripherally. This fact will ensure a more functional, safe, and fast crossing close to key locations of the park, particularly the amphitheatre, the event yard/venue, and the square to the west of the car park, and it will also ensure access to the educational facility in the north. Cycle parking is being considered at every entrance to the cycling path as well as the educational facility. 
The main entrances to the park are at Avenida do Empresario and the corners on the north side. The route system is based on a functional and efficient design. It is based on preexisting buildings and morphology determining flows and accesses that enable us to immediately reach the different spaces within the park. These axes along the south are also where the infrastructures are settled and formalise the main entrances to the valley. (Fig. 5)

Here (the valley to the south), cultural continuity is defined within a straight and vernacular relationship between Man and the earth, which emphasises the productive role and encourages the associated biodiversity. The compartmentalised mosaic is redesigned in a more urban version. The unfolded detention ponds in the valley are used to water the vegetable garden, the vines, the olive grove, and the orchard on the hill where the parcels mix together. (Fig. 6)

A well proportioned riparian gallery accompanies the waterline, as is the case with the landscape, ensuring that the energy and matter continue to flow downstream towards the lagoon and the city's park.

To the north, with a more urban ambience, the projected design has aesthetically altered the morphological elements that give it its shape. From the heart of this subspace comes a more open basin that has expanded over the landscape, a circle of water that closes the shell and enriches it with the biodiversity and ambience that it provides. Classified as a 'singularity', on a slope to the south of this arena, from the ridge, is an amphitheatre facing the castle as well as part of the city, to the north-west, and the contour of Serra da Gardunha and Serra da Estrela, over the horizon. (Fig. 7)

A maintenance circuit appears in the north of this area. Meandering, it goes in and out of the park, extending its offer to Castelo Branco athletes, who have been establishing Castelo Branco as a reference in Portuguese running over the past years. The multi-functionality of this route, permanent contact with the functional features of the main circulating structure, and the informal articulation established with the periphery enable us to cross the entire park. At the beginning/end of the circuit, we foresee sports equipment (apparatuses) enabling the practice of a few exercises.

Watering, drainage, and lighting shall be ensured throughout the park and based on the principle of sustainability (using rainwater that falls on the detention ponds for watering and LED lights for less energy consumption), and last but not least, providing different ambience in order to provide different park user experiences.

Urban furniture (benches, paper baskets, signs...) will be placed throughout the entire landscape making it functional and safe to any type of usage or stay.

The playground will be made by manipulating/modelling the land as opposed to traditional equipment.

The proposed living and inert materiality is a reflex of that provided by the landscape as raw material: mortarless masonry walls, cork, flower-filled meadows, and the sense of a bucolic landscape come in through the new park in the city. (Fig. 8)

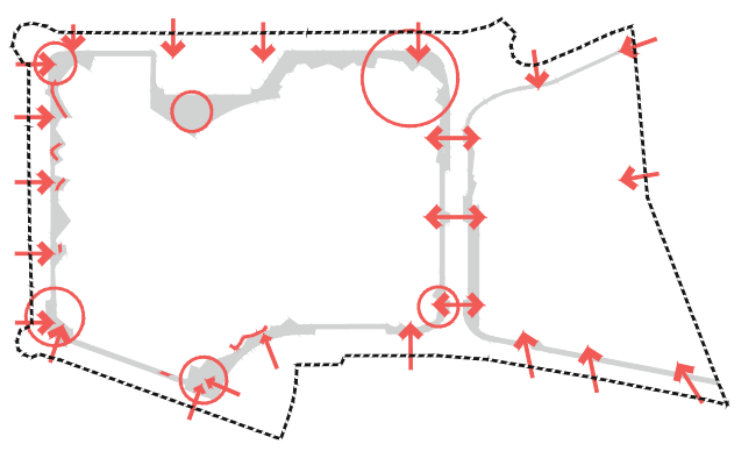

Figure 5. Park entrances

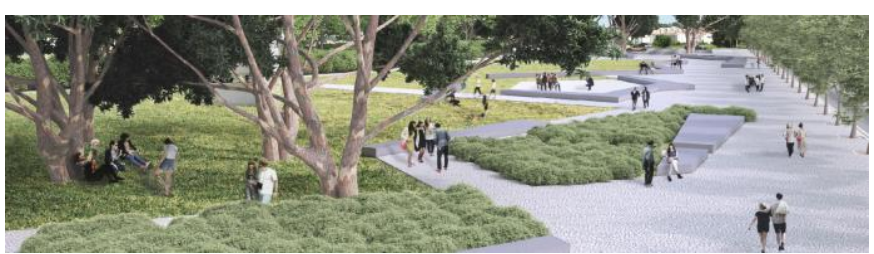

Figure 6. More urban ambience

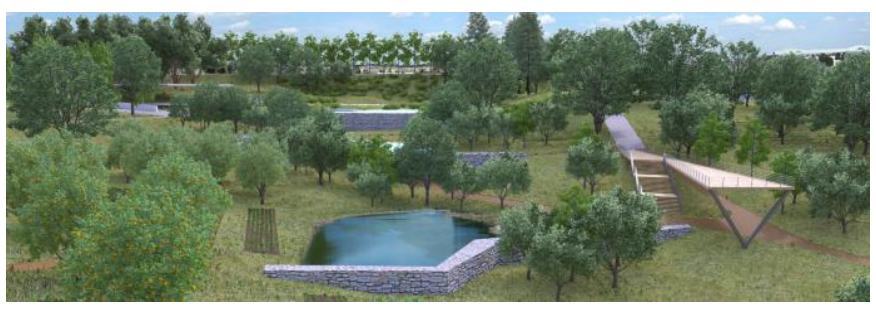

Figure 7. Water promoting biodiversity
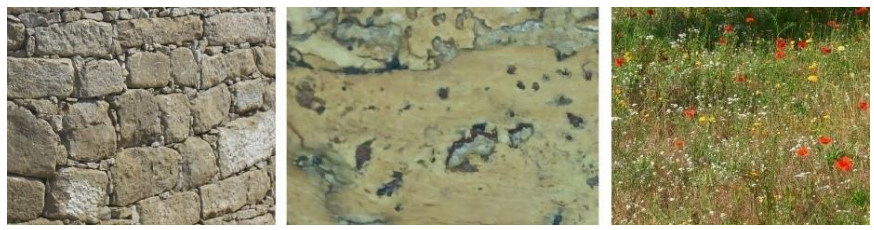

Figure 8. Different matters present in the park

\section{VEGETATION SYSTEM}

The proposed vegetation is based on the pre-existing vegetation and phyto-sociological characteristics of the area. There is, originally, a climatophilous cork-oak forest, which is part of the Smilaco asperae-Querco suberis sigmetum series, and in terms of vegetable dynamics, its mature stage is formed by dense woods filled with oak trees. With the destruction of these woods, the cork-oak forest gave way to a set of trees near woodland designated as strawberry trees, which were enriched by junipers. The second stage of replacement took place in the fringes of the forest with the appearance of a broom field. A vivacious meadow grows on deep soil and is maintained by means of intensive pasture or cutting.

The park's morphology is emphasised and highlighted through the vegetation, which is predominantly native: occupied and empty areas are built with the different extracts; areas of shadow and light are defined; ridges and thalwegs are highlighted. Colour variation and freshness are felt throughout 
the year within a constant and cyclical renewal creating a Locus amoenus greeting the population. (Fig. 9) Inspired by (37), we come to realise that the vegetation's certain promiscuous heterogeneity is the key to biodiversity, particularly due to the establishment of bird species, which we intend to encourage: 'The embroiderers of Castelo Branco made a wonderful flora and fauna on their candlewick spreads, not far from zoology as per fleeting glimmer raised into the starry sky of imagination by real things, which are out of sight.'

The adopted and adapted patches of eucalyptus remain a memory of usage as well as their strength, density, dimensions, and freshness.

The olive trees are also a clear and fair memory of the cultural systems in the Beira's landscape and they set the pace, particularly to the north of the park.

The present mulberry trees and pomegranate trees have a cultural basis and stand out in Castelo Branco's embroidery as is the case with the species that produce small fruit, which may include the following, among others: Prunus spinosa, Arbutus unedo, Myrtus communis, Pistacia terebinthus, Juniperus lagunae, out of which the latter are a part of the dominant vegetation.

Pine trees and oak trees are a part of the vegetation in the dominant phyto-sociological series and are the 'trees of life' for the park, once again alluding to Castelo Branco's embroidery, where the tree of life is constantly present.

The shrub vegetation appears in the park in a meandering and biomorphic manner. It contains spaces; it sustains slopes, and formalises the periphery taking the role of a textured reinforcement within the park's limitations.

The flower-filled meadow prevails as a cover, and the different cutting times differentiating the patches throughout the year shall be a reason for reducing maintenance costs and ecological and colour richness. Exceptionally, in small areas such as those surrounding the amphitheatre and the water mirror, and the patio's reception area by the dam -, there is grass, which is watered, cut, and capable of taking on greater human load.

For plastic purposes - delimiting structural features and ranks -, as well as adaptability to biophysical conditions and Castelo Branco's pre-existence, some ornamental species have been proposed: the sweet gum, in order to delimit the structural features due to its size, shape, texture, and the colour of its leaves.

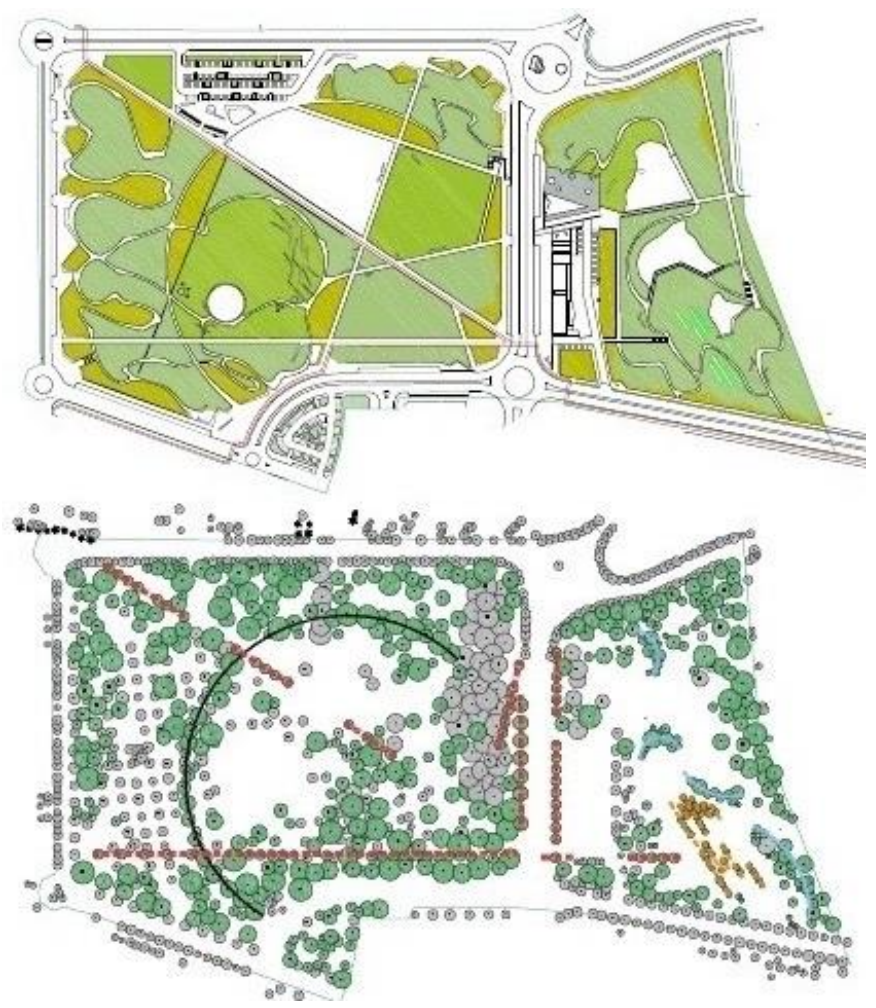

Figure 9. The park morphology underlined with vegetation

\section{ROUTE SYSTEM}

The pavements come to life in the form of coatings, which, once again, are based on pre-existing ones, ecological issues, and sustainability. The entire pavement along the park takes the form of a small walkway that promotes continuity and integration into the surrounding urban tissue due to the use of the same material on the surface coat.

For the same reason, the lines crossing the park structure the space's morphology and design, and come to life as a larger or smaller walkway depending on the necessary load capacity for their task and their hierarchy. Once these lines come loose from the surface and are elevated, their material of choice is wood, which is light and forms a part of the space creating suspended belvedere over the park's landscape, mastering an immediate involvement, and emphasising a look upon the hills within a far horizon.

Now, the maintenance circuit is covered with disaggregated material, hence allowing for rainwater infiltration in accordance with the intended sustainability.

The cycling path will be covered with porous concrete in order to provide a stable and homogeneous floor and also enable water infiltration.

Car parks will be covered with asphalt and walkways in order to be integrated with the pavement, although it will be more stable and economic due to the use of asphalt. 


\section{CONCLUSION}

The proposed landscape is, within the context of this study case, just like the common landscape, of a cultural nature, with a development of the mind and spirit of men by means of cultural phenomena that depend on sensitivity and aesthetic considerations based on a natural datum. This line of thought leads us to thinking that we belong in a landscape-related culture: 'appreciating landscape depends on an intimate and a cultural relationship with the world, where the landscaperelated culture will powerfully contribute to the creation of new forms of law in society over nature.'

Landscape will then appear as an idea, a construction, which results from the actions of men over nature and territory. According to (5), we would prefer if landscape was not broken into what is natural and cultural. We choose to consider it a unique entity whose greatness and value originate from it being indissociable. A holistic concept, which results from a dynamic system that is constantly transforming and evolving, hence constituting an expression of the people's identity. The idea of a space for vital experience is also an essential matter within the concept of a landscape. Landscape is, in fact, not just a space for contemplation, but it is also a space for experiencing and living, even when you are contemplating.

Nowadays, you come to realise that the new demands of consumption society increase its interest in these landscapes the Mediterranean continues to be a place where you will be reunited with ecosystems and cultures, which holds great multi-functionality and potential. Two conflicting worlds touch each other, each one of them resulting from an ecological stage of the history of humanity: an agricultural stage, which modelled the Mediterranean landscape reaching a precarious balance after thousands of years of co-evolution between Man and nature, and an energetic stage, which projects the consequences of the growing demands of urban and industrial societies into the environment.

The world of high energy (28) is without a doubt one of the areas of the plant where Man's activity is more intense and subsequently exercises great pressure on the landscape. This was altered after many centuries of balanced usage similarly to that which occurs with other phenomena in today's consumption society - the impact on landscape has entered an accelerated phase of exponential growth. But, at the same time, other social demands have developed as a reflex of human nature's social needs and the crisis felt. It is simultaneously an exciting challenge and an unavoidable risk to be able to meet these demands so that society and the environment may last in time.

Within this context of Mediterranean landscape multifunctional potentials, there can and should arise actions combining production (agriculture and forest production) with ecosystem regulations and information on nature, geology, history, and aesthetics, among others, as proposed for Parque Urbano de Montalvão. This way, there must coexist combinations of food production, housing, recreational activities, water management, nature management, and cultural preservation within the same land use system. Landscape multi-functionality, as the name implies, must include many functions within the same space - and is greater when maintained either simultaneously on several levels, or within the several traditional land use systems.

\section{REFERENCES}

[1] Lei de Bases do Ambiente. Lei n. 11 de 7 de Abril de 1987. (1987) Artigo $5^{\circ}$, alínea c)

[2] Convenção Europeia da Paisagem. Decreto n. 4 de 14 de Fevereiro de 2005. (2005). Artigo 1

[3] F. Caldeira Cabral. Paisagem. In: Enciclopédia Luso-Brasileira de Cultura, vol. 14. Lisboa: Verbo, 1973

[4] G. Ribeiro Telles. A cidade e a paisagem global do século XXI. In: J. Caetano (Coord.) A utopia e os pés na terra, Gonçalo Ribeiro Telles. Lisboa: Instituto Português de Museus. 2003.p. 332-340.

[5] A. Spirn, The granite garden: urban nature and human design. New Haven/London: Yale University Press, 1984, p.3

[6] A. Cancela d'Abreu, T. Pinto Correia and R. Oliveira. Contributos para a identificação e caracterização da paisagem em Portugal Continental (vol 1). Lisboa: Direcção Geral do Ordenamento do Território e Desenvolvimento Urbano (DGOTDU), 2004. p. 32

[7] M. Magalhães. Paisagem - Perspetiva da Arquitetura Paisagista (p. 109). In: A. V. Serrão, (Ed.), 2007.

[8] J. B. Jackson. A la découverte du paysage vernaculaire. (Collection Actes Sud). Paris: École Nationale Supérieure du Paysage. p. 10

[9] F. Burel and J. Braudy, Ecologye du Paysage: concepts, méthodes et applications, Paris: Tec \& Doc-Lavoisier, 2001.

[10] R. Assunto, Paesaggio e l'estetica. Natura e storia (Vol.1. Napoli: Giannini editore, 1973. p. 163

[11] M.V. Ferriolo, Etiche del paesaggio. Il projetto del mondo umano. Roma: Editori Riuniti, 2002. p. 15

[12] J. Maderuelo, Paysage y territorio. Madrid: Abada Editores, 2008. p. 6.

[13] G. Bernáldez. Ecologia y Paisaje. Madrid: H. Blume Editiones, 1981.

[14] R. S. Matos, A Reinvenção da multifuncionalidade da paisagem em espaço urbano - reflexões, Tese de Doutoramento, Évora: Universidade de Évora, 2011.

[15] G. Clément. Manifiesto del Tercer Paisage. Barcelona: GG mínima, 2007. p. 6.

[16] P. Donadieu. Campagne urbane, una nuova proposta di paesqggio della città. Roma: Donzelli Editore, 2006

[17] C. Waldheim (Ed). The landscape urbanismo reader. New York: Princeton Architectural Press, 2006

[18] G. Ribeiro Telles. Paisagem global: um conceito para o futuro. In: Iniciativa, $\mathrm{n}^{\circ}$ especial, 1994,Abril.

[19] J. Gaspar, D. Abreu and J. Ferrão (Dir) Portugal: os próximos 20 anos. Ocupação e organização do espaço. Uma perspectiva (vol.6) Lisboa: Fundação Calouste Gulbenkian, 1989

[20] P. Birot, Portugal. Lisboa: Livros Horizonte, 1970

[21] Braudel, F. (1995). O Mediterrâneo e o Mundo Mediterrânico, (vol. 2, $2^{\text {a }}$ ed. p. 620). Lisboa: Publicações D. Quixote.

[22] C. Cavaco. Portugal rural: da tradição ao moderno. Lisboa: Ministério da Agricultura, 1992

[23] Y Luginbuhl (Dir.). Paysage méditerranéen. Catalogue de l'exposition "Paysage méditerranéen » organisée dans l'Exposition Universelle de Séville de 1992, 5 juin-12 octobre 1992, ELECTA, Milan, 317 pages, illustrations N\&B et couleurs, quatre éditions: français, espagnol, anglais, italien, 1992.

[24] G. Bernáldez. Ecologia y paisage. Madrid: H. Blume Editiones, 1981

[25] M. R. Corredor-Guinard. L'orientalism et le paysage méditerranéen. In: Mappemonde 1 (92)

[26] F. Forneau. Voyageurs en Andalousie et représentations touristiques d'un certain paysage méditerranéen. In: Y Luginbuhl (Dir.). Paysage méditerranéen. Catalogue de l'exposition "Paysage méditerranéen " organisée dans l'Exposition Universelle de Séville de 1992, 5 juin-12 octobre 1992, ELECTA, Milan, 317 pages, illustrations N\&B et couleurs, quatre éditions : français, espagnol, anglais, italien, 1992. 
[27] I. Zannier. Le paysage photographié au cours du grand tour méditerranéen. In : Y Luginbuhl (Dir.). Paysage méditerranéen. Catalogue de l'exposition "Paysage méditerranéen » organisée dans l'Exposition Universelle de Séville de 1992, 5 juin-12 octobre 1992, ELECTA, Milan, 317 pages, illustrations N\&B et couleurs, quatre éditions: français, espagnol, anglais, italien, 1992.

[28] J. P. Sanz and J. Alamo. Demandes sociales de paysage dans la région méditerranéen. In: Y Luginbuhl (Dir.). Paysage méditerranéen. Catalogue de l'exposition "Paysage méditerranéen » organisée dans l'Exposition Universelle de Séville de 1992, 5 juin-12 octobre 1992, ELECTA, Milan, 317 pages, illustrations N\&B et couleurs, quatre éditions : français, espagnol, anglais, italien, 1992.

[29] S. Daveau. Portugal Geográfico. Lisboa: Sá da Costa, 1995

[30] A. Girão. Esboço de uma carta regional de Porrtugal ( $2^{\mathrm{a}}$ ed.). Coimbra: Imprensa da Universidade. 1933
[31] P. Matvejevich. Breviário Mediterrânico. Lisboa: Quetzal Editores, 1994

[32] O. Ribeiro, Portugal, o mediterrâneo e o atlântico, Lisboa: Ed. Sá da Costa, 1986.

[33] R. Soeiro de Brito (Dir.). Portugal. Perfil geográfico. Lisboa: Estampa, 1994.

[34] C. Norberg-Schulz, Genius loci, paysage, ambiance, architecture, Hayen:Pierre Mardaga, 1981.

[35] J. Gaspar. As regiões portuguesas. Lisboa: Direção Regional do Desenvolvimento Regional, 1993

[36] P. M. S. Simões, Guardiões da paisagem - os montes alentejanos. Lugares de memória, Tese de Doutoramento, Évora: Universidade de Évora, 2015.

[37] M., M., I., Rosa. O Bordado de Castelo Branco, Caleidoscópio. 2009 